\title{
"Appointment" and Spontaneous Field Situations: Ethnographic Fieldwork in the Hungarian Communities of American Industrial Towns and Mining Settlements
}

\author{
Balázs Balogh \\ Institute of Ethnology, RCH, Hungarian Academy of Sciences, Budapest
}

\begin{abstract}
To create context, the study first recounts, in a nutshell, the emigration history of Hungarian Americans and the main features of their American integration. In addition to discussing the specific fieldwork goals and experiences, the article seeks to present the theoretical background of the fieldwork concept of the research. The author began his research in the United States in 2006, where he has been regularly returning to conduct ethnographic fieldwork ever since. From the great emigration wave that began at the end of the nineteenth century up until today, he examines the history, institutional networks, and socio-ethnographic aspects of Hungarian communities on the East Coast and in the Midwest, including acculturation, identity change, and contacts with the homeland. When developing his fieldwork concept, for his guiding principle he chose to combine the individual identity construction model with capsule theory. Hungarian American emigrants who have been forced to switch cultures have been living their lives in a "time and mentality capsule". The part brought from the old country resides inside the capsule, while everything outside is part of the new environment. This duality can be complemented by the potential role of the local community, which directly surrounds the individual in the alien new country. Examination of this particular capsule is only possible in the field. In the course of fieldwork, the main question becomes: to what extent do the adopted patterns of behavior, the desire to meet American social expectations, and the efforts that are internally controlled and realized, allow a look into these capsules? Such fieldwork is characterized by a duality of scheduled appointments pre-arranged with prospective informants, and spontaneous field situations. In the Hungarian communities of industrial towns, fieldwork consisted predominantly (almost exclusively) of the "appointment" type of data collection, while in the case of former mining settlements on the brink of extinction, spontaneously developing ethnographic data collection was more typical. Participation in events linked to dates and venues, data collecting at these occasions, and getting acquainted with event participants for later interviewing is the third option besides the fieldwork situations mentioned above. Finally, the paper attempts to demonstrate through several examples of the ways in which fieldwork can enrich the information gained from documents with additional data, tangible memorabilia, and the memories related to them.
\end{abstract}

Keywords: Hungarian Americans, immigration, fieldwork methods, minority communities, time capsules 
In this paper, presenting my fieldwork method among Hungarian Americans, first I would like to provide a concise summary on the emigration history of Hungarian Americans and the major trends of their American integration. ${ }^{1}$ Next, I describe my research work in the United States, in order to contextualize the specific targets and experiences of my fieldwork. In line with this goal, I outline the theoretical background of the methodology I applied during my subsequent field studies.

In the United States, nearly 1.5 million people claimed to be of partly Hungarian origin, according to the data of the 2000 census which also inquired about the ethnic background of parents and grandparents. ${ }^{2}$ In the decades preceding World War I, the approximately 650-700 thousand Hungarian immigrants ${ }^{3}$ were the first major wave of migration to America (PuSKÁs 1981:33-34; 1984:145-164; VÁRDY 1985:21). The first immigrants settled predominantly in the Midwest and on the East Coast, ${ }^{4}$ primarily in coal mining areas (Pennsylvania, Ohio, West Virginia, etc.), where they worked on mining sites isolated from the world (in Hungarian-American parlance, "plézeken" / "in places") (JENKS - LauCK 1913:70) (Figure 1), and starting at the turn of the $20^{\text {th }}$ century, also in the heavy industry (mainly in steel factories, iron foundries, and railways). The "Little Hungary" neighborhoods of Northeastern America came into existence at this time, such as Burnside in Chicago, Delray in Detroit, Hazelwood in Pittsburgh, the largest one being the Buckeye neighborhood in Cleveland. ${ }^{5}$ (Figure 2) At the same time, Hungarian workers' colonies of thousands strong were established near several small industrial towns (McKeesport, Johnstown, Lorain, Youngstown, Akron, Uniontown, South Bend, etc.) (JENKS - LAUCK 1913:73-75). In their new American home, the members of the first Hungarian immigrant generation of peasant origins - mostly landless farmhands and smallholders - formed ethnic colonies in both the mining settlements and the urban industrial districts. The everyday use of their mother tongue and common social

\footnotetext{
${ }^{1}$ I have published many studies on the emigration history of Hungarian Americans and the main features of their social integration in the United States. Here I only refer to my foreign-language studies. BALOGH 2010a, 2010b, 2013.

2 An important feature of the American census is that one can report multiple identities. Up to four identities may be reported, one for each grandparent. Today, nearly 1.5 million people consider it important to report that they are at least a quarter Hungarian. Total declared Hungarian/Magyar ancestry were 1,398,724 persons in the United States in 2000, according to census data published by the United States Census Bureau.

Table 1. First, Second, and Total Responses to the Ancestry Question by Detailed Ancestry Code: 2000 https://www.census.gov/data/tables/2000/dec/phc-t-43.html, PDF format of Census 2000 PHC-T-43. Table 1. First, Second, and Total Responses to the Ancestry Question by Detailed Ancestry Code: 2000 https://www2.census.gov/programs-surveys/decennial/2000/phc/phc-t-43/ tab01.pdf\# (accessed November 14, 2018) Code 125 Hungarian (First Ancestry 903,963, Second Ancestry 494,028, Total 1,397,991) and Code 126 Magyar (First 699, Second 34, Total 733). Total of declared Hungarian/Magyar Ancestry together 1,398,724.

${ }^{3}$ At the turn of the $20^{\text {th }}$ century, American emigration was a common phenomenon in Southern and Eastern Europe. 25 million Europeans emigrated to America in the five decades preceding World War I, including about 2 million Hungarian citizens. JONES 1992:361; BROWNSTONE et al.1979:4-5.

${ }^{4}$ In 1922, 427,000 of the 474,000 Hungarians lived in the northeastern states, most of them in New York $(95,400)$, Ohio $(88,000)$ and Pennsylvania (86,000). Souders 1922:55; VÁrdy 2000:244.

${ }^{5}$ For the settlement types of Hungarian immigrants, see: VÁrDY - VÁrdY HuszÁr 2005:195-205.
} 


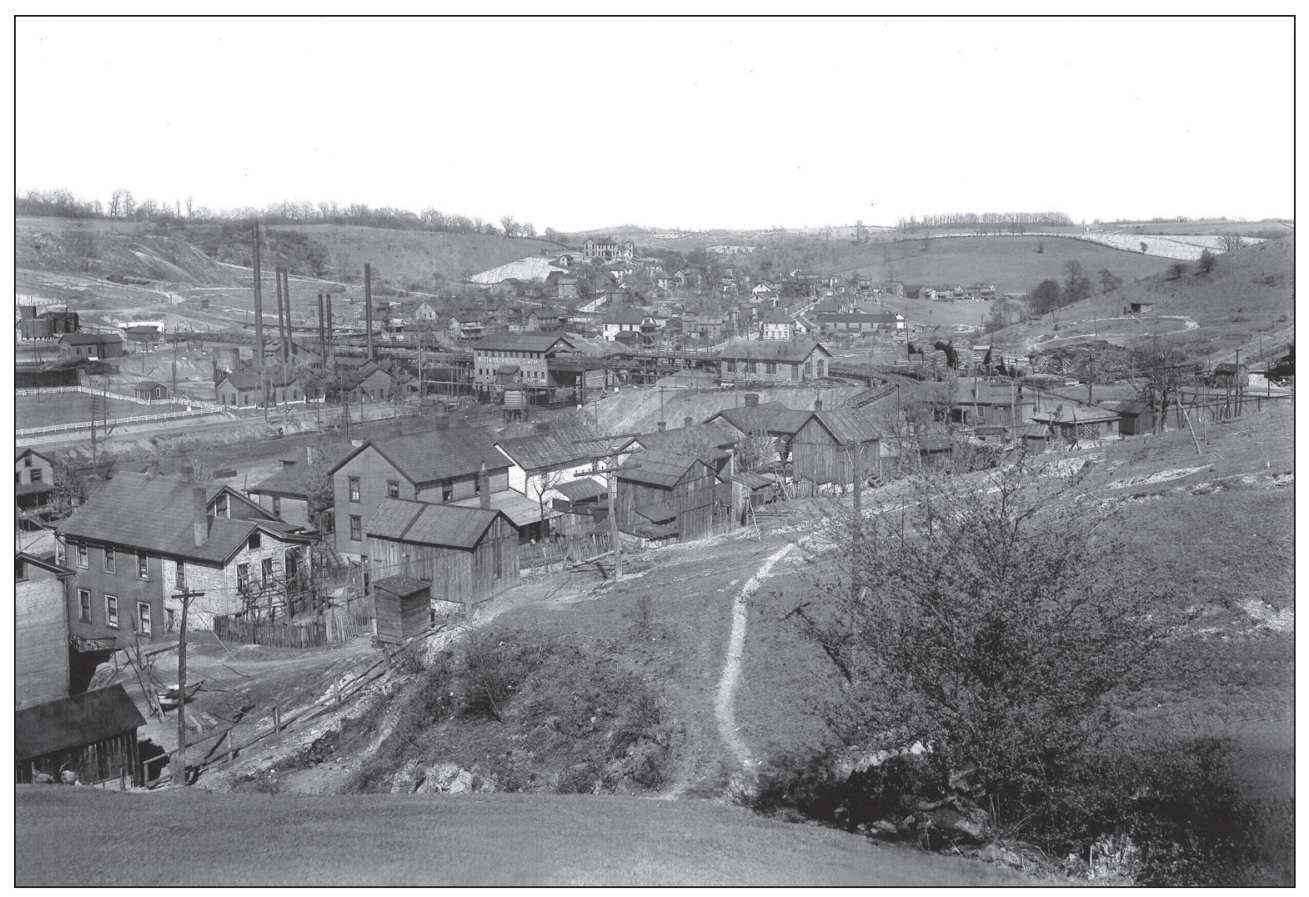

Figure 1. Westmoreland Mining Company's Mine \#2. Pennsylvania, 1918. Photo by John Sartoris

interactions took place in a relatively homogeneous Hungarian environment. There was a Hungarian shop in the Buckeye district in Cleveland where a sign said, "We also speak English!” (BALOGH 2008:12).

Following World War II, the next important and significant wave of emigration from Hungary to the United States were the so-called "DPs". The abbreviation comes from the term "displaced person" ${ }^{\prime}$ and indicates emigrants that left their homeland after World War II, mostly for political reasons, including some 110,000 Hungarians. However, the flock of people referred to collectively as "DPs" was far from homogeneous, and the American host country also made a distinction between its various layers. Those who left Hungary in 1945 and those who came in 1947 were at odds with each other, and the Americans also regarded the former more as war criminals, while the latter as a group that more or less underwent a democratization process and left before the Communist takeover of 1948 (VÁRDY 2000:458-462). "DPs" were mostly intellectuals - state officials, clerks, diplomats, gendarmes, military officers, aristocrats, etc. - whose skills were especially difficult to "convert" in American society, and many of them were middle-aged, learned

\footnotetext{
${ }^{6}$ Despite the unclear definition of DP in Hungarian everyday language, I am not averse to its use, as it clearly and accurately describes the refugee wave following World War II in the history of Hungarian emigration and in the works addressing it, and it is a common term used in social and historical sciences.
} 


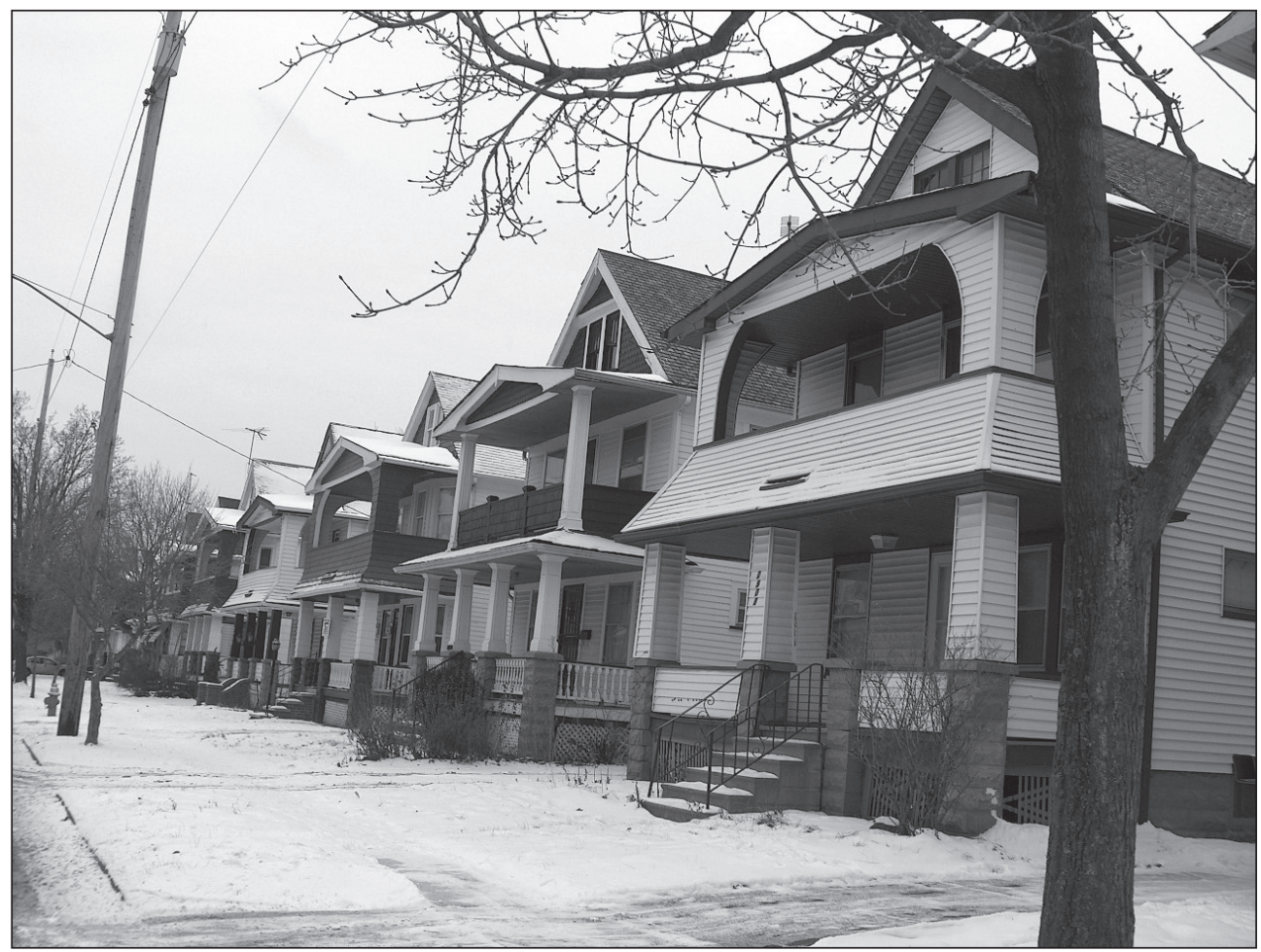

Figure 2. The Hungarian neighborhood of yore, Buckeye Road neighborhood. Cleveland (OH) 2009. Photo by Balázs Balogh

people with families. These learned, intellectual "DPs" found it difficult to fit into the environment of the old-timers ("öreg amerikások") 7 of peasant origins.

The third well-defined emigration wave was that of the "Fifty-sixer" refugees. Their arrival further subdivided and nuanced the already polarized Hungarian-American society, which was made up of several strata of "DPs" and the second and even third generation of old-timers. This Fifty-sixer immigrant wave was made up in part of people with secondary or higher education, generally scientists, particularly hard science intellectuals and trade school graduates, but a greater portion was made up of skilled and unskilled industrial workers. Most of them were single men, which in itself determined much in the integration process, from social mobility to marriage preferences. Individuals arriving with the different emigration waves maintained (and developed further) a different image of the homeland, having come from different backgrounds and thus representing different value systems and mentalities (BALOGH 2010b) (Figure 3).

I will forgo getting into the continuous, trickling rather than wave-like, predominantly economic migration of the late socialist and post-regime change era.

\footnotetext{
7 The original Hungarian expression "öreg amerikások" is used by Béla Várdy as "old-timers", see: VÁRDY 1985:99.
} 


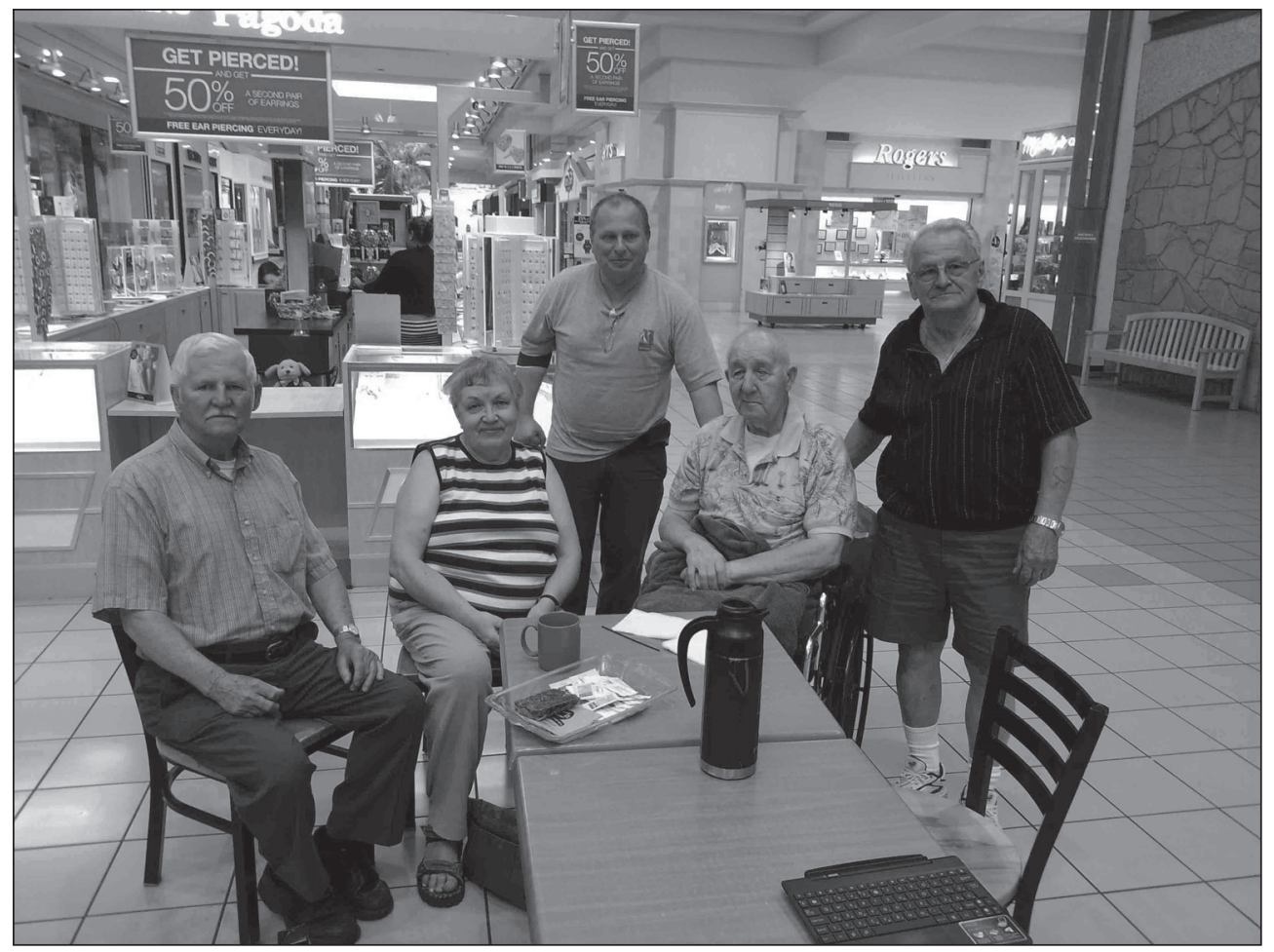

Figure 3. Weekly meeting of Fifty-sixers in a café in a mall. Rev. Péter Tóth in the center. Lorain $(\mathrm{OH})$ 2015. Photo by Balázs Balogh

I started my research in the United States in 2006, and I have been regularly returning there to conduct ethnographic fieldwork ever since. I have been researching the history, institutional networks, and socio-ethnographic aspects of Hungarian communities on the East Coast and in the Midwest from the great emigration wave of the late $19^{\text {th }}$ century up until today, including the issues of acculturation, identity changes, and contacts with the homeland. During my fieldwork, I try to give voice to each generation, which involves studying the living environment of the informants, their everyday lifestyle (clothing, nutrition, etc.), family documents and photographs. ${ }^{8}$

As for my fieldwork concept, as a guideline, I elected to use the joint application of the individual identity construction model and of capsule theory. In the case of Hungarian Americans, the universal model is also applicable, according to which the identity construction of an individual belonging to a particular minority can be situated in a three-pronged coordinate system, determined by his/her attitude toward the homeland (the Old Country) on the one hand, the host country on the other, and thirdly, to the narrower environment of his/her own minority community. The schema of factors that

\footnotetext{
${ }^{8}$ Research also extends to the study of documents found in archives, but this paper is focused on the particulars of fieldwork.
} 
shape minority identity construction is tied to Roger Brubaker's name (BRUBAKER 1996), but scholars studying the identity of Hungarian Americans (e.g., VÁRDY 2000, NAGY 1984, Fejös 1993; SzÁntó 1984; Papp 2008; VÁrdy - VÁrdy Huszár 2005; Balogh $2010 \mathrm{~b}, 2013,2015)$ have been conducting their research according to the above criteria even before this modelling was formulated. Hungarian Americans that emigrated and have been forced to switch cultures have been living their lives in a "time and mentality capsule." The concept of time capsule has been used since 1937, referring to a container containing objects of old times or, in a wider sense, information from older times. Thus, we can regard it as a kind of communication with the future. Objects, writings are placed in a container in order to send messages to the people of the distant future. According to historian William Jarvis, most intentionally created time capsules intend to convey unusable, worthless information, in contrast to the Pompeii artifacts buried by the ash of Vesuvius, which, though random, contain a lot of important information, and thus can be considered a time capsule (JARVIS 2002). It is the concept of this specific time capsule that I would like to extend more broadly and symbolically to the examination of minority ethnic groups, in order to illustrate what mental, relational, and material environments individuals and groups create to experience and express their identity constructs.

Just as an aside, it bears mentioning that it has been well documented by linguists that those who leave their home take with them and pass down to their descendants (if they pass it down at all) the language use, the jargon that was common in their time. Their language development is delayed (if change can be even referred to as development); if an older man in America uses the slang expression "oltári pipa vagyok" ("I'm mighty ticked off", meaning very angry), then we can be certain that he is not a descendant of immigrants that came before World War I, but a Fifty-sixer Hungarian. This expression is not even used by those who immigrated later, as it has not been heard among young people at home either, because it "went out of style."

In order to capture the phenomena I experienced more precisely, and applying to them the term "time and mentality capsule", I will try to characterize them differently. An individual finding himself/herself in a physically and socially different environment will try to influence his relationship with the world around him even within the new environment. He will try to order his physical environment in the usual way and strive to maintain his human relationships with those linguistically and culturally similar to him, whom he understands and who easily understand him, and of course, he will be enveloped by an invisible veil of a mentality that determines how he behaves. All this could be called simply force of habit, too, but the term 'capsule' expresses this situation more eloquently, because fixed action patterns, cultural conditioning, and everyday life are now being created in a completely strange environment. The processes take place as if capsules of various durability were being dropped en masse into an ocean of liquid. The effects of the new environment may diffuse through the walls of the capsules slower or faster, depending on the durability of the capsule's wall, but the capsules will nonetheless resist the external environmental influence for a certain period of time. This analogy can be taken further within the conceptual framework of the three-dimensional schema of minority identity construction: on the inside of the capsule is the part brought from the Old Country; what is outside is the new environment. This duality can be supplemented by the potential role of the local community that surrounds the individual in his strange new home: where the capsules coming from the same place are arranged tightly side by side (i.e., Hungarian 
workers' colonies, "Little Hungary" neighborhoods of industrial towns, Hungarian mining settlements), they reinforce each other - like small bubbles merging into one big bubble, or like small droplets of oil in water converging to make an oil patch with a shared external wall - and these combined, thicker walls are then better able to protect the contents brought from the Old Country. Inside this mentality capsule surrounding the individual - and sometimes even communities - are all the contents through which one is connected to the Old Country, to Hungarian identity and culture, in this multitudinous but despite all homogenizing and globalizing effects still mosaic-like, colorful American culture.

In persons who in the censuses declared themselves Hungarian (by identity and/or language) or who simply recognize their origins, identity characteristics are best observed during fieldwork. Elements of identity preservation that manifest themselves in mentality features, souvenir use, eating habits, fixed behavioral patterns, and many other details, can usually only be scraped together bit by bit, through painstaking work. The disappearance of the walls of time and mentality capsules indicates assimilation to American society, which can never be complete in the first generation of adult immigrants. In the second, third and subsequent generations, the capsules' walls generally become thinner and more perforated, with less and less of an "inner world" of culture, identity, and mentality rooted in the Old Country and more and more of homogenized American elements, the walls finally disappearing altogether and assimilation becoming more complete as their inner content comes to match their outer environment. But this, of course, can also take place at a different pace and rhythm depending on micro-community, age group, family, and individual.

This peculiar capsule can only be examined in the field. The main question in the course of fieldwork is: to what extent do the adopted patterns of behavior, the desire to meet American social expectations, and the efforts that are internally driven and truly lived, allow a look into these capsules? It is important to understand that the process of Hungarian peasants' American embourgeoisement is also characterized by the ambiguity of the above-mentioned compliance and inner motivations! To what extent does American society, which operates in a dialectic of hierarchized social structure and conformity with the consumer value system, conceal these capsules? For, on the one hand, in America, a worker is a worker, a miner a miner, a teacher a teacher, and though all civil and personal rights are being observed, the respect that various levels of prestige demand varies and is hence dependent on hierarchy. At the same time, compliance with the consumer value system is the only valid comparative scale in society. All of these work against making mentality and cultural differences visible, and thus the inner contents of the capsules are becoming more and more difficult to examine. Simply put, the biggest challenge in the course of my fieldwork was to find out how far below the surface of adopted behavioral patterns do the peasant, the gentry, the lord, or the "lad of Pest" lurk in the immigrants arriving with the various waves of immigration detailed above. ${ }^{9}$

Let me illustrate with some short examples how, in various field situations, it was possible to gain an insight into these time and mentality capsules in the case of a former servant of peasant origin, a military officer from pre-war Hungary, and a Fifty-sixer laborer from Angyalföld.

${ }^{9}$ That is, young people involved in the demonstrations and street fighting of the 1956 Revolution in Budapest. 


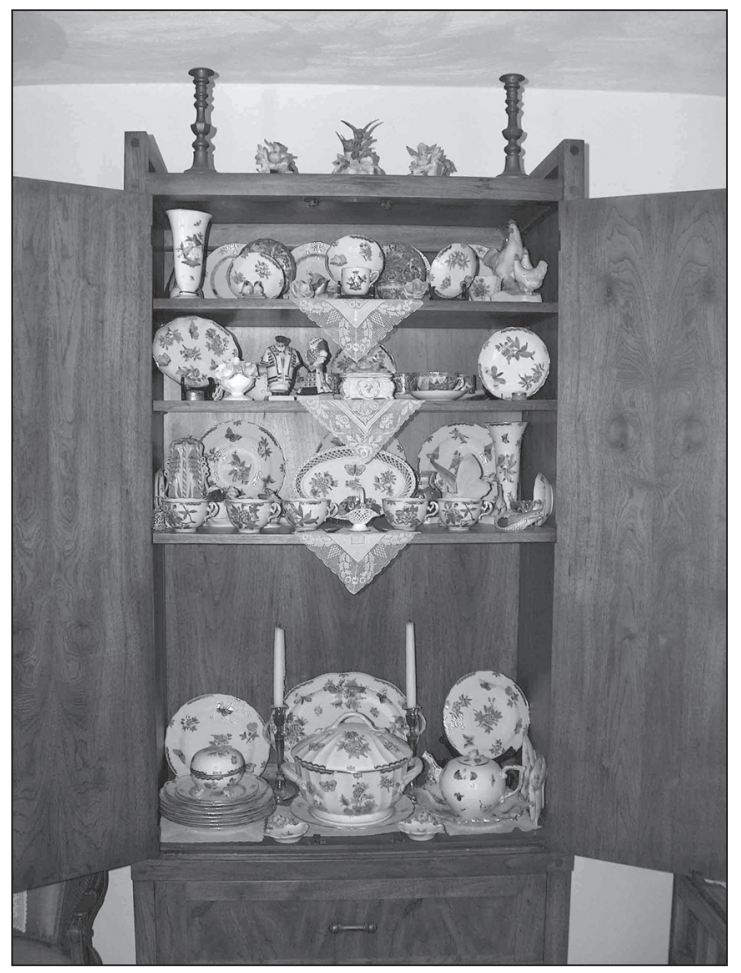

Figure 4. Porcelain from Hungary in the home of T. K., a former maid. Ligonier, 2007. Photo by Balázs Balogh
First example: T.J., an elderly woman in the Bethlen Communities Home Health and Hospice in Ligonier (Pennsylvania) (formerly "nursing home"). Very few of the current residents here are of Hungarian origin. Knowing that Auntie T was a first-generation Hungarian, and that she was a servant in Hungary before the war, I wanted to interview her. At first, she vehemently refused to talk: "There is nothing interesting in my life!" "I'm the same as all the other old women in America", etc. After having spent weeks in the archives of the Bethlen Home and seeing her every day, sometimes we would stop to talk about neutral things - weather, upcoming holidays, and so on. Finally, upon the recommendation and personal intercession of the only Hungarian caregiver there, I managed to gain access to her. Then she invited me to tea in her apartment at the Bethlen Home. Here I noticed that she furnished her room and kitchen with a very Hungarian

flair. When asked about a piece of furniture, ornament, or embroidered pillowcase, she responded readily and willingly. Just as in Hungary, if informants see and feel that the interviewer is familiar with the tradition and the material world in which they live, they open up much more readily. That is how the world of her interesting, personal "capsule" was revealed to me, in which she wore a peasant-style headscarf and housecoat at home, while her civilian street clothes matched the standard American clothes - for life outside the capsule. She added another mattress to her bed so that it would "be as tall as the peasant bed in Hungary," as she explained to me. Behind the building (in which she lived), she was cultivating a small garden with the permission of the Bethlen Home, where she planted tomatoes and paprika seedlings brought from Hungary. She made Hungarian dishes and used Hungarian paprika for seasoning. The most striking thing, however, was that she had filled her apartment with expensive porcelain and decorative objects from Herend and Hollóháza, in an attempt to compensate for the poverty she had lived in as a servant. "I've always loved these (porcelain items), they are beautiful! But we could not even dream about them in Hungary. Now whenever someone is going home for a visit, I have them bring me some of these." (Figure 4)

Second example: L.Z., former military officer, at the World Federation of Hungarian Veterans' Charity Ball in Cleveland (Ohio). I attended the ball of the WFHV - established in Austria after World War II in 1949 - upon the invitation of the local 
Honorary Consul. The ball is always a grandiose display of formalities: debutantes in their "díszmagyar" enter the ballroom flanked by rows of men standing in a sword salute. ${ }^{10}$ The Honorary Consul led me to the table of the WFHV leaders and their guests of honor. When he announced who I was and that I came from Hungary, there were some reluctant introductions - they treated me disparagingly and with suspicion so as to discourage me from sitting at their table. They made it obvious, with loud remarks, that to them I was just a "Kádár kid" from Hungary. "Kádár kids" are people who grew up in Hungary during socialism (and were thus "infected" by communism), referred to as such primarily by "right-leaning" DPs and Fifty-sixers. ${ }^{11}$ During the introductions, I noticed the name of G.K. because this family name was so rare, and because my physician grandfather had talked about it often. I asked if he was a doctor and from Debrecen. Taken by surprise, he responded by asking how I knew this. I told him who my surgeon professor grandfather was, and that I heard his name in various family anecdotes. At this point G.K., who emigrated after 1956, became extremely friendly, announcing loudly to the entire leadership at the table of honor that "we have nothing to fear, he is not from a communist family, his grandfather was an 'icon' as he was the only surgeon professor in Hungary who was not a member of the Party." This was the moment when I was passed from decorated "vitéz" to decorated "vitéz" and they all talked with me, including a former military officer, L.Z.: "Come here, please, what's new at home? Do you still go to the Arany Bika ${ }^{12}$ in Debrecen?" etc.

Third example: T.A., Fifty-sixer, former laborer from Angyalföld, in Grand Rapids, Michigan. (Figure 5) I met him through a Calvinist pastor, visited him in his home after we made an "appointment". Because I was recommended by the pastor, he received me civilly and recounted his brief life story with a focus on 1956. But not much was revealed to me about the internal motivation of his emigration, the details of resettlement, integration, "putting down roots". However, I found out from his narrative that before the Revolution of 1956, he frequented a jazzclub in Angyalföld where my future fatherin-law played jazz music. (I knew this for sure when I mentioned this club.) At that time, jazz music was considered reprehensible - or at the least a barely tolerated "Western blight" - in socialist Hungarian cultural policy. As it turned out, he had also known my father-in-law, "Füles", from the Dagály swimming pool, because "all the cool people from Angyalföld went to the Dagály in the summer", as he put it, and then he went on to list the names of "old buddies", including my father-in-law's, lamenting that he never saw again those who stayed home. When I made it clear to T.A. that "Füles", the jazz musician he mentioned, was my father-in-law, he completely opened up to me and we

\footnotetext{
10 "Díszmagyar" (lit. fancy Hungarian dress) is the popular name of the representative men's and women's gala dresses that evolved from historic Hungarian noble attires during the 19th-century national awakening, worn by nobles and the middle-class gentry on representative occasions and formal national festivals until the end of World War II as an expression of their national and political identity. In Hungary, the communist revolution obliterated its use, but in Western immigrant communities, such as in the United States, the wearing of the díszmagyar has survived until recently.

${ }^{11}$ János Kádár, the first secretary of the Hungarian Socialist Workers' Party, was a lead figure after the Soviet and anti-Communist Revolution of 1956, and the period between 1956 and 1988, referred to as the "Kádár era", was named after him.

${ }^{12}$ The Arany Bika (Golden Bull) is a famous old, elegant restaurant and hotel in Debrecen.
} 


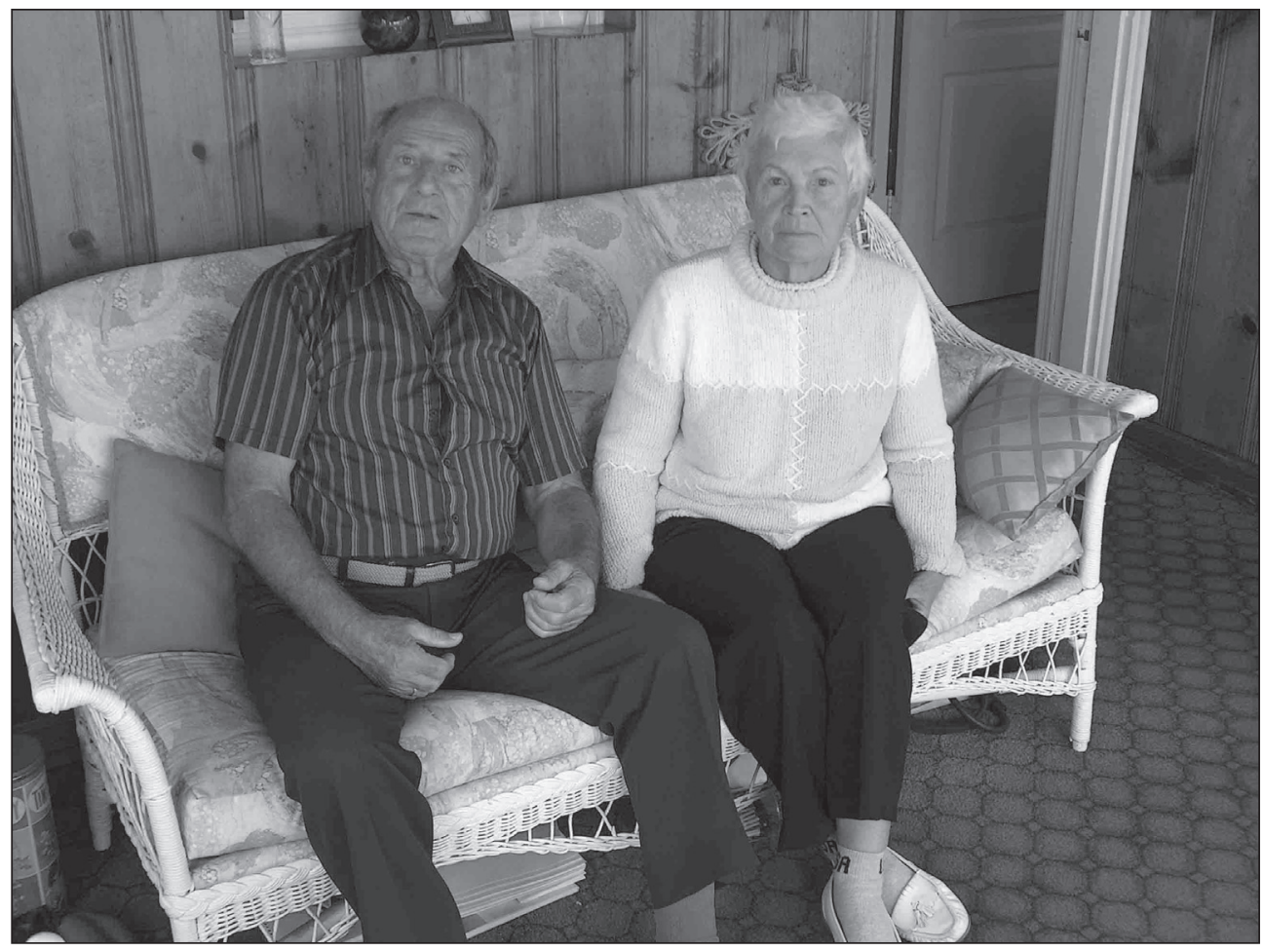

Figure 5. T. A., a Fifty-sixer with his wife. Grand Rapids (MI) 2009. Photo by Balázs Balogh

talked till dawn. He revealed to me even the most personal details of his life history. He acknowledged his trust in me by talking until dawn sitting in the hot tub and finishing off a bottle of whiskey. The "capsule" has been opened...

After these three examples, I would also like to highlight the specific characteristics of field situations that raise countless questions. What does a researcher visiting the former Hungarian neighborhoods, the former Hungarian colonies around the mines and factories that are now closed find today? Do the Hungarian groups that just a few decades ago functioned as cohesive communities still hold community events? What kind of institutional frameworks exist that might bring together the different age groups and thus make them more visible, more researchable (nursing home, cultural club, scouting, weekend Hungarian school, church life, etc.)? What kinds of data collection situations does the researcher face when trying to find a Hungarian informant in the concrete jungle of a metropolis or in a former mining colony of a few hundred souls? Where and with whom can one still speak in Hungarian and who are only agreeing to doing interviews in English? And where there are no more Hungarians, or they have completely assimilated, do the cemeteries, churches and other memorials bear witness to the past? Finally, how can we give a voice to the written documents through the local artifacts and the tools of oral history?

The researcher visiting the former Hungarian neighborhoods around the closed factories today is greeted with a depressing view. The dynamically developing, labor-intensive 


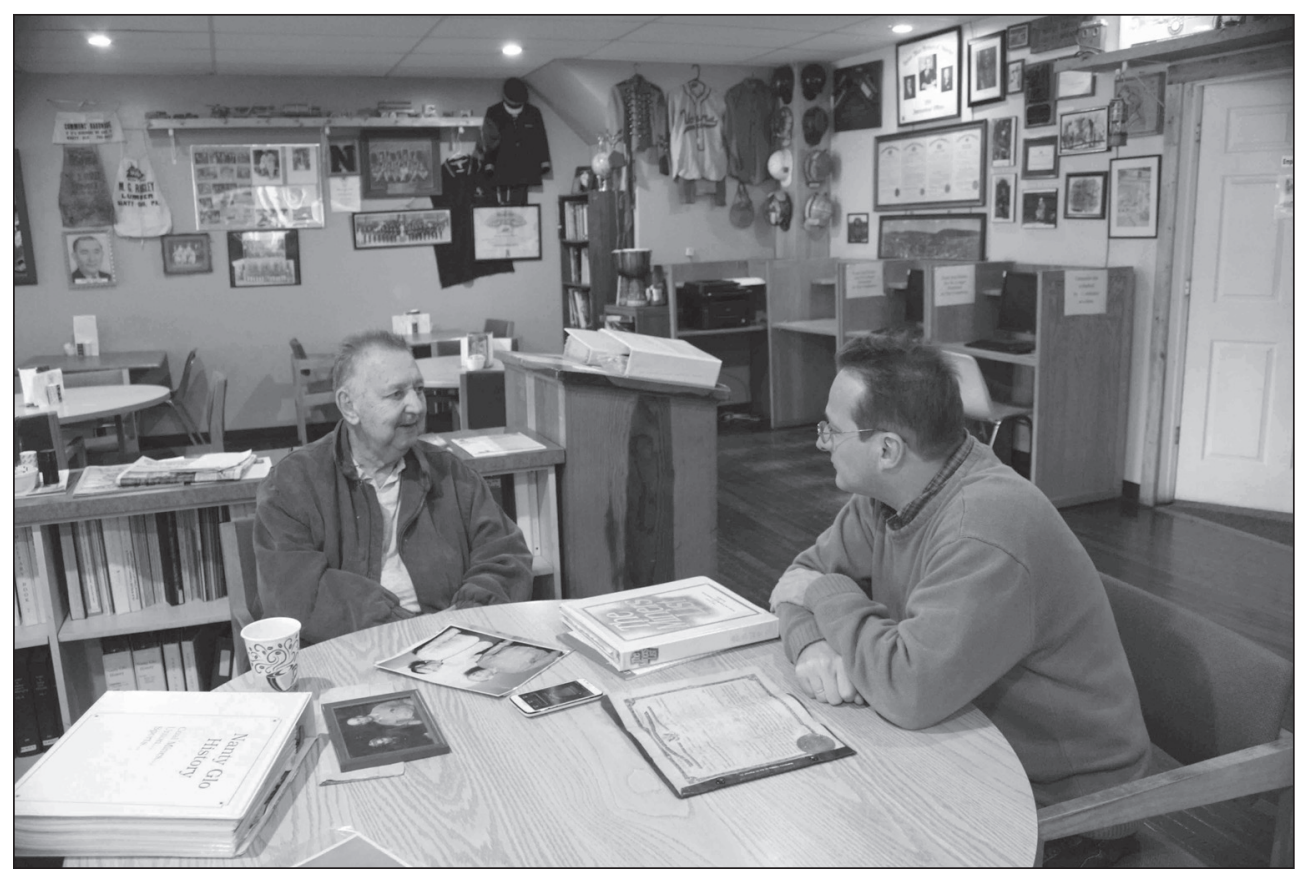

Figure 6. Béla Tóth responding to questions by Balázs Balogh in the miners' archive in Liberty Cafe. Nanty Glo (PA) 2014. Photo by Ágnes Fülemile

industrial districts of the turn of the $20^{\text {th }}$ century are today a scene of decay and misery, partly depopulated, partly "slumified". The situation is usually similar in the formerly thousands-strong Hungarian colonies around the megafactories of smaller industrial towns and the dying, shrinking mining colonies near closed mines, inhabited predominantly by helpless old people, unemployed derelicts, alcoholics, and drug addicts.

Such fieldwork opportunities are characterized by a duality of scheduled appointments arranged with prospective informants and spontaneous field situations. In the Hungarian communities of industrial towns, fieldwork consisted predominantly (almost exclusively) of the "appointment" type of data collection, while in the case of former mining colonies on the brink of extinction, spontaneously emerging ethnographic data collection was more typical. Participation in events associated with specific dates and venues, data collection during these occasions, and getting acquainted with program participants for later interviewing is the third option in addition to the fieldwork situations mentioned above.

The "appointment" type of data collection opportunities usually emerge through an intellectual network. Here I must note that in the United States, the Hungarian intelligentsia with a strong sense of Hungarian identity is very close-knit, almost "everyone knows everyone", from California to New York and from Florida to Michigan. In fact, one can only find informants in big cities with some help. It is always worthwhile asking for the advice of the intellectual who plays a central role in the life of a given community, but it is not always easy to explain to them what the ethnographer is interested in. Without making an appointment by telephone, one cannot find informants "just off the street". (Figure 6) Asking for advice, however, is usually not enough, because having a 
phone number and a name does not guarantee that the person will agree to a personal meeting. Having a personal introduction is generally more conducive to success. A concrete example of this is how I found a 102-year-old Hungarian woman in Portage (Pennsylvania) through a pastor. The pastor first talked to the woman on the phone and agreed with her on a time ("made an appointment") and then escorted me personally to her apartment. He introduced me, we talked together for about fifteen minutes, and when the informant seemed receptive and happy to talk to me, he left us alone. The woman even had personal, childhood memories of the boat trip from the 1910s. ${ }^{13}$ Even when one asks for advice, the choice of informants is not always failproof. In South Bend (Indiana), while wandering around the former Hungarian neighborhood of Rum Village, I asked the owner of the formerly Hungarian Charley's Bar and Budapest Night pub about Hungarian informants. He recommended a Hungarian cook named Marika in another part of the city, whom I visited. After a couple of questions, it turned out that the woman was Slovak. In several cases, I have found that Americans with purely Slovak roots believe that they are of Hungarian origin. "We heard that my grandfather came from Hungary" - which was true! But that did not mean that he was ethnically Hungarian. Prior to World War I, this was not as important as in later periods. ${ }^{14}$ For example, the Hungarian Reformed Federation, a fraternal association, would insure people of other religions as well, because the principal criterion was that people from Hungary have a Hungarian insurer, the main factor being a common homeland, not nationality. In looking for informants, another problem could be a consultant who plays a central role in community life not understanding what the researcher might be interested in. So whoever s/he refers us to, who s/he says "knows everything", may in fact tell us "nothing" about the life of the Hungarian community that the researcher could evaluate.

The difficulties of fieldwork here are quite different from ethnological research in the Carpathian Basin and navigating data collection in the Hungarian language area. Even finding a church in a smaller town is difficult without help, let alone an informant. In Windber (Pennsylvania), I searched for the former Hungarian, Roman Catholic Church of the Virgin Mary for hours in pouring rain. I even showed a photograph of the church to the few pedestrians I encountered (TӧRÖK 1978:309). Eventually, I found a person in solitary prayer at the Polish church whom I asked about the Hungarian church upon leaving. He remembered that it had been demolished four years earlier because the nearby hospital needed the space, had paid good money for it, and there were hardly any Hungarian believers anymore. ${ }^{15}$ The Polish informant even knew that the church bell was in the Hungarian cemetery in a small memorial that commemorates the decadeslong existence of the erstwhile Hungarian church. (Figure 7)

\footnotetext{
${ }^{13}$ The interview was made in 2015.

${ }^{14}$ In a multinational historical Hungary, citizens maintained a loyal "Hungarus" consciousness. The expression of national and ethnic identity became more pronounced for many groups and individuals after the fragmentation of Hungary in 1920 following the Trianon peace treaty.

${ }^{15}$ The American dioceses of the hierarchical Roman Catholic Church generally do not or rarely care for the ethnic background of the communities that built their churches. If a congregation is having difficulty maintaining a church, the diocese either closes it or sells it, or fills it with churchgoers of other ethnicities.
} 


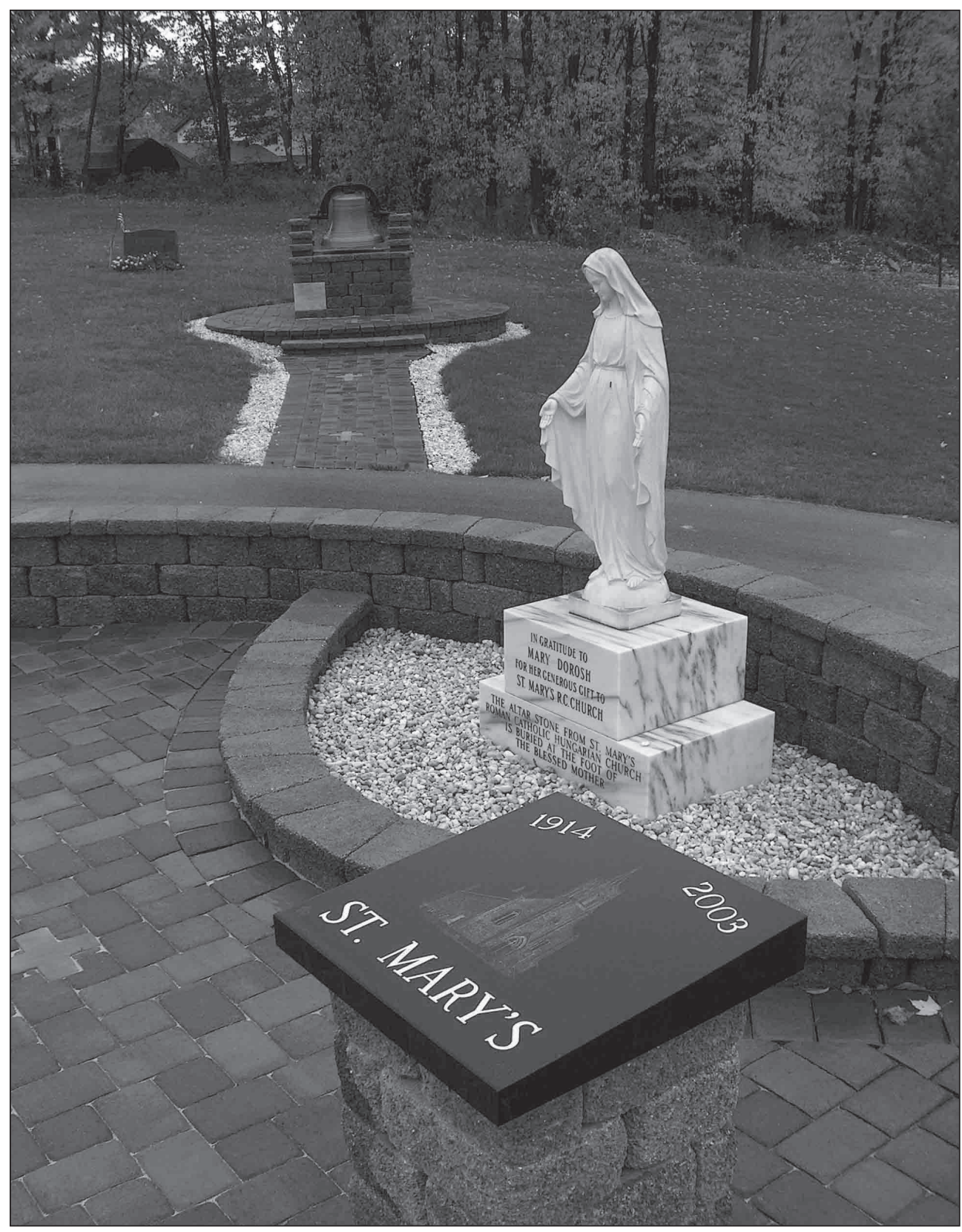

Figure 7. Plaque and bell of the Church of the Virgin Mary, demolished in 2003, in the Hungarian cemetery. Windber (PA) 2007. Photo by Balázs Balogh

Hungarian events. An opportunity to attend Hungarian events is only possible in places where there is still a Hungarian community. To participate in an event, it is also essential that one get news of it, and if it is a private event (such as balls, like 


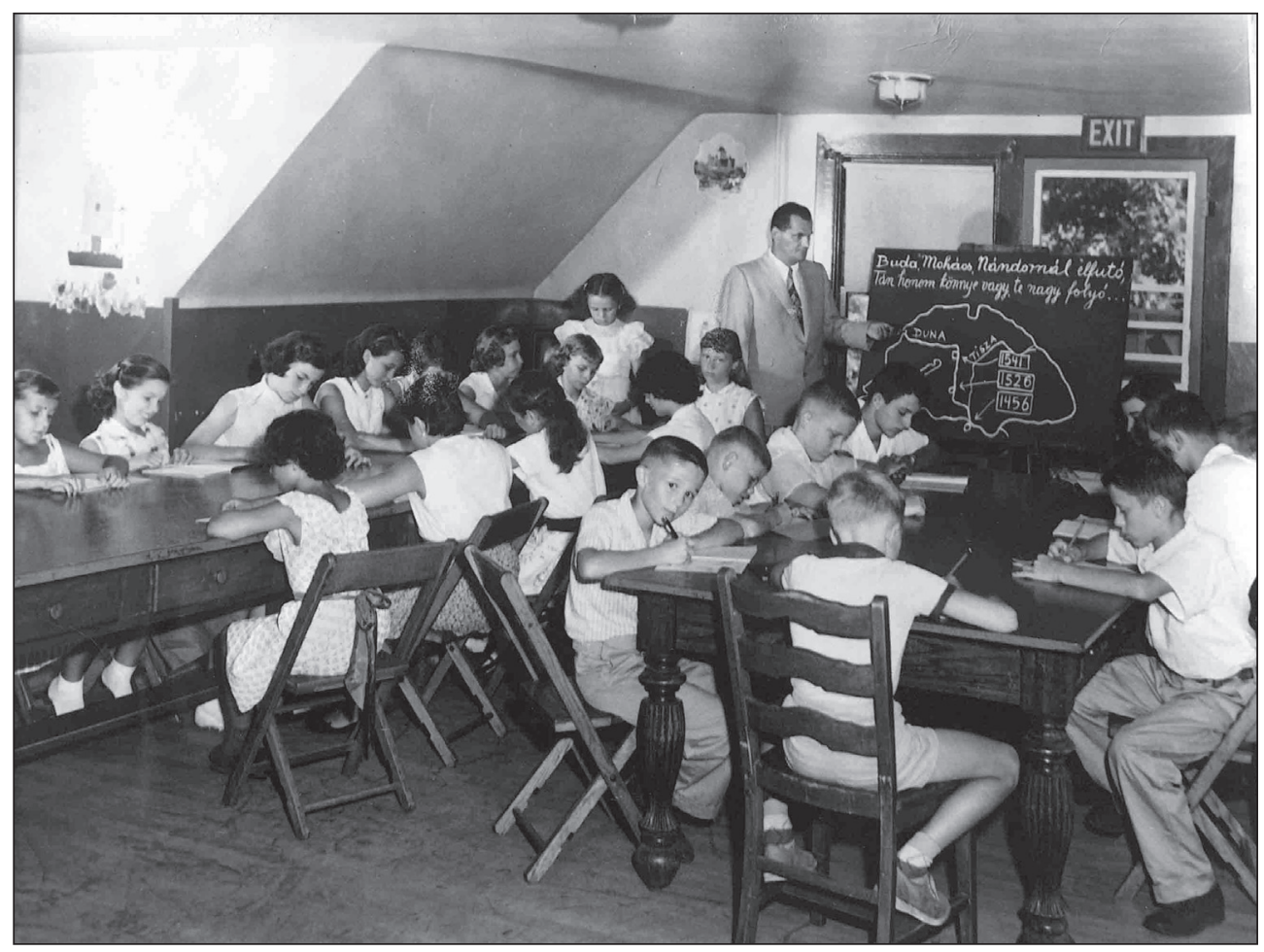

Figure 8. Hungarian school. Ligonier $(\mathrm{OH}), 1970$ s (from the Archives of the Bethlen Home)

the World Federation of Hungarian Veterans' ball in Cleveland described above), to secure an invitation. The church as a main organizer, the Hungarian cultural clubs, the Hungarian school (Figure 8), and Scouting (Figure 9) do somewhat unite the scattered families that are still committed to participating in Hungarian programs. The former Hungarian colonies, the "Little Hungary" neighborhoods of big cities, have permanently disintegrated. The time when experiencing Hungarian identity and the everyday use of the mother tongue was effortless has passed. The possibility of "Hungarian contacts" in the former, relatively homogeneous, continuous Hungarian environment is no longer. What may have remained in the former Hungarian neighborhoods were the churches, the buildings and scenes of Hungarian community institutions, but the Hungarian families have scattered, and the erstwhile Hungarian environment has, almost without exception, undergone slumification. For decades now, it has taken great effort and sacrifice to ensure the "survival of Hungarians". Often Hungarian families come to the Hungarian church from hundreds of miles away, bringing their children to the weekend Hungarian school and scouting, attending Hungarian cultural events, commemorations, and festivals. This is how the formerly thousands-strong Hungarian communities became "weekend Hungarians". Events are of paramount importance in Hungarian American life, as these are the only occasions when communities can experience the feeling of belonging. Year after year, the number of Hungarian events dwindles. The disintegration process of the communities can be considered natural from a historical perspective: dispersal due to 


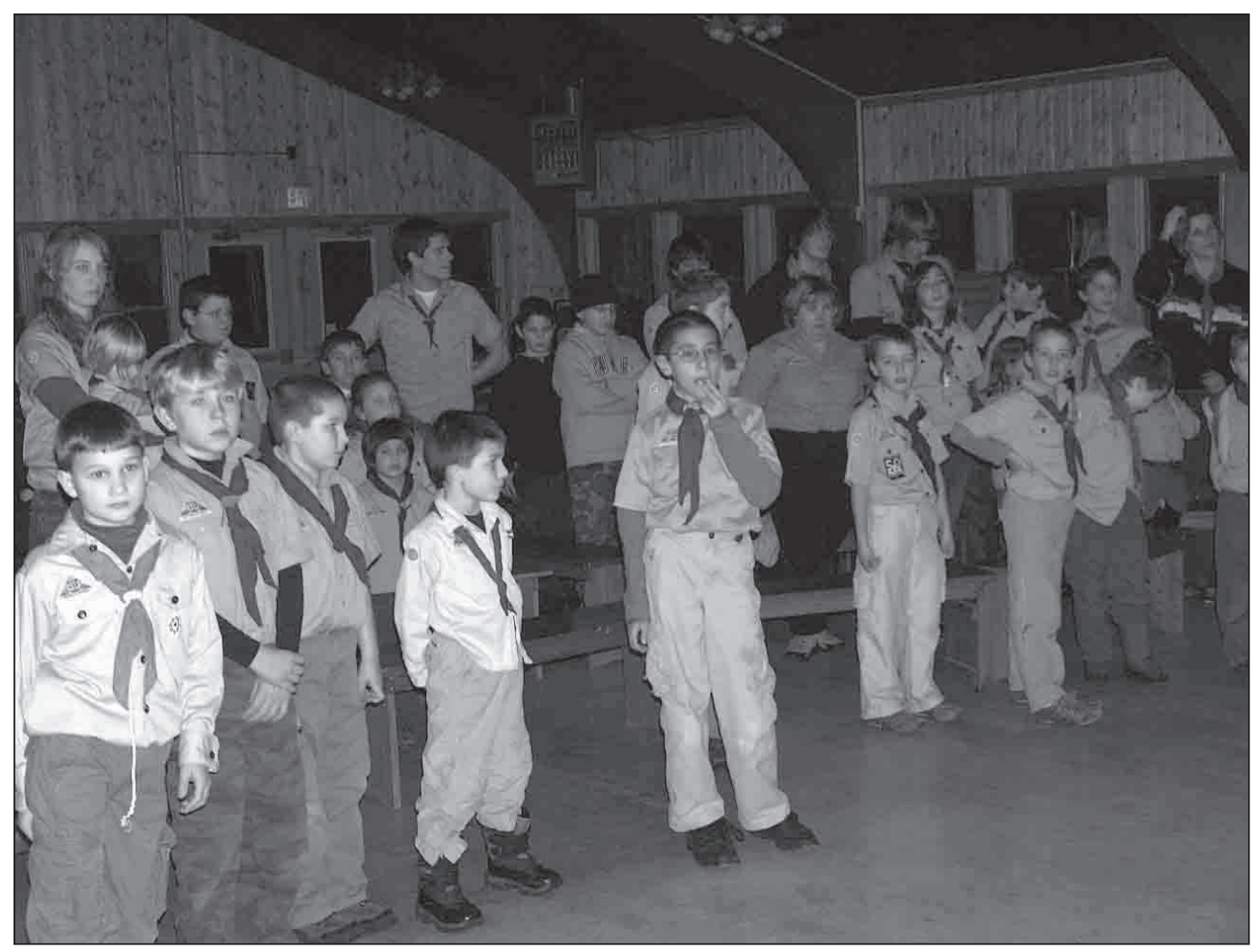

Figure 9. Scouts. Cleveland, 2008. Photo by Balázs Balogh

labor migration, the language switch of new generations, and the slow agony of the institutional network are general milestone in the process of assimilation (BALOGH 2008). Spontaneous field situations tend to emerge in smaller settlements, predominantly in former mining colonies. In this case, the researcher cannot arrange the data collection in advance - because in most cases it is impossible to do. Especially around the mining sites of Pennsylvania, West Virginia, and Ohio, there were a number of small, isolated colonies with significant Hungarian populations of miners, which the Hungarian Americans called "pléz" (place). Some of the hundreds of former mining sites have ceased to exist. Some settlements were liquidated and the dismantled buildings sold off as boards; $;^{16}$ in other places, the abandoned houses were simply overgrown by vegetation and slowly decomposed. (In Pennsylvania, the route of a former coal pipeline linking the extinct mines, called Ghost Town Trail, was established as a tourist attraction to revitalize local tourism. ${ }^{17}$ ) Nonetheless, many of the former mining sites, though languishing and with a fraction of their former populations due to the lack of job opportunities, do still exist. From church documents and the registers of fraternal associations, we can find out which settlements had the largest numbers of Hungarian miners. Based on these, it is worth

\footnotetext{
${ }^{16}$ E.g., Wehrum (Pennsylvania).

${ }^{17}$ The 58-kilometer-long railway line connects Black Lick with Ebensburg (Pennsylvania).
} 


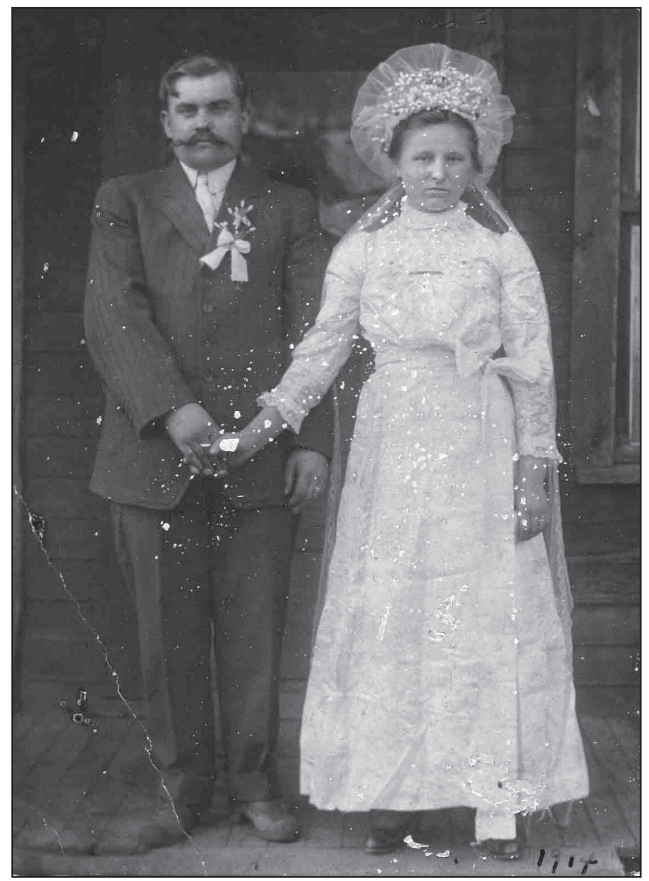

Figure 10. Wedding photo. Vintondale, 1914. Hugya family

settlement that was once two thousand strong but now dwindled to around three hundred and fifty. According to their concordant recollections, "there was a grand Hungarian life here!" The Hungarian community retained its community festivals - until the end of the 1970s, the lads went around sprinkling at Easter and chanting at Christmas-time. Until the 1950s, whenever there was a Hungarian wedding, they hired Gypsy musicians from Johnstown and danced the csárdás. (Figure 10) Until World War II, they only spoke Hungarian in the streets. Almost everyone kept animals and held big pig slaughters. Many even had meat smokers. Every woman cooked Hungarian style (BALOGH 2007). In 1928, forty people were confirmed in the Reformed Church at the same time; the depopulation that has taken place since is well reflected by the fact that the last confirmation in Vintondale was over ten years ago. In 2007, there were about eight to ten people attending the monthly worship service, while in 2015 there were only two or three.

With the slow but steady closure of the nearby mines, Vintondale was becoming depopulated, as was the entire mining region. There was a surplus of old buildings on the real estate market and no demand for so many dwelling houses. This is how a once Hungarian-owned building that served as a "burdosház" (boarding house, cheap housing for miners or laborers) - and which until the Great Depression of 1929 housed a

${ }^{18}$ The area of the former historical Hungary in Central Europe surrounded by the Carpathian Mountains. 


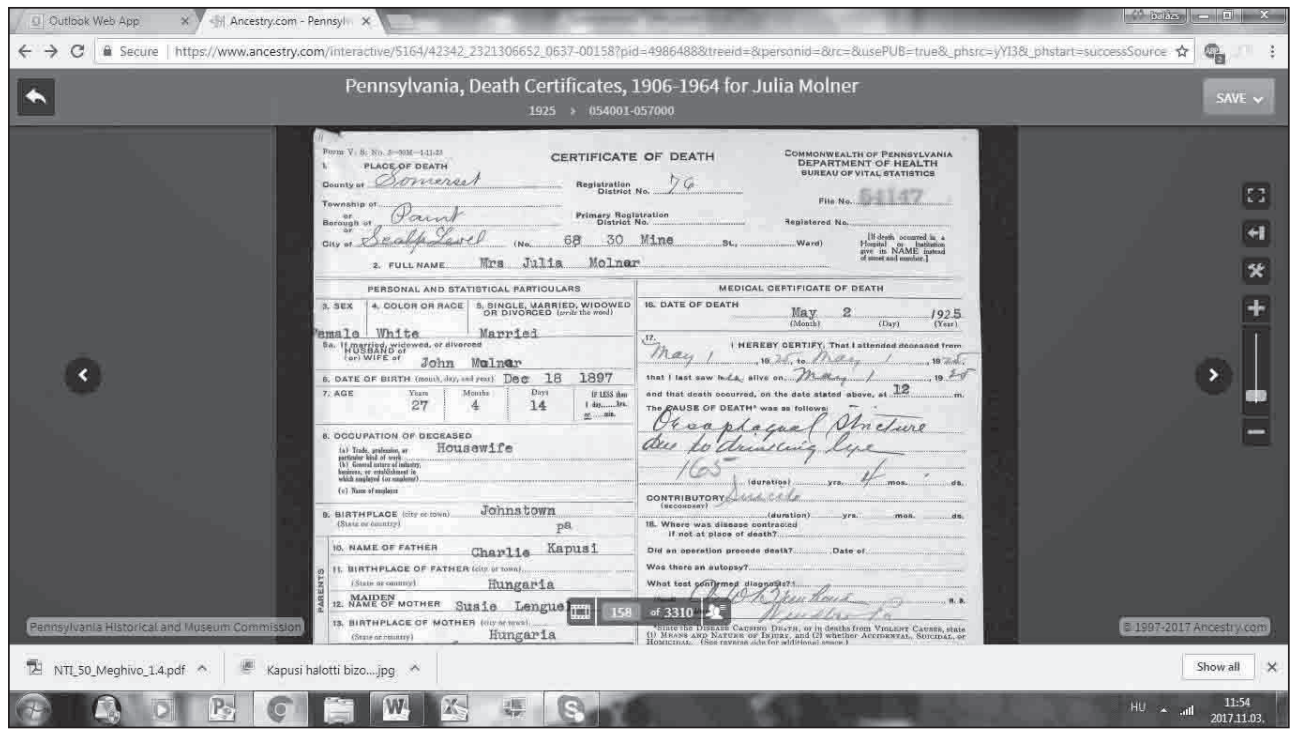

Figure 11. Death certificate of Júlia Kapusi on a website. Cause of death in the right lower corner

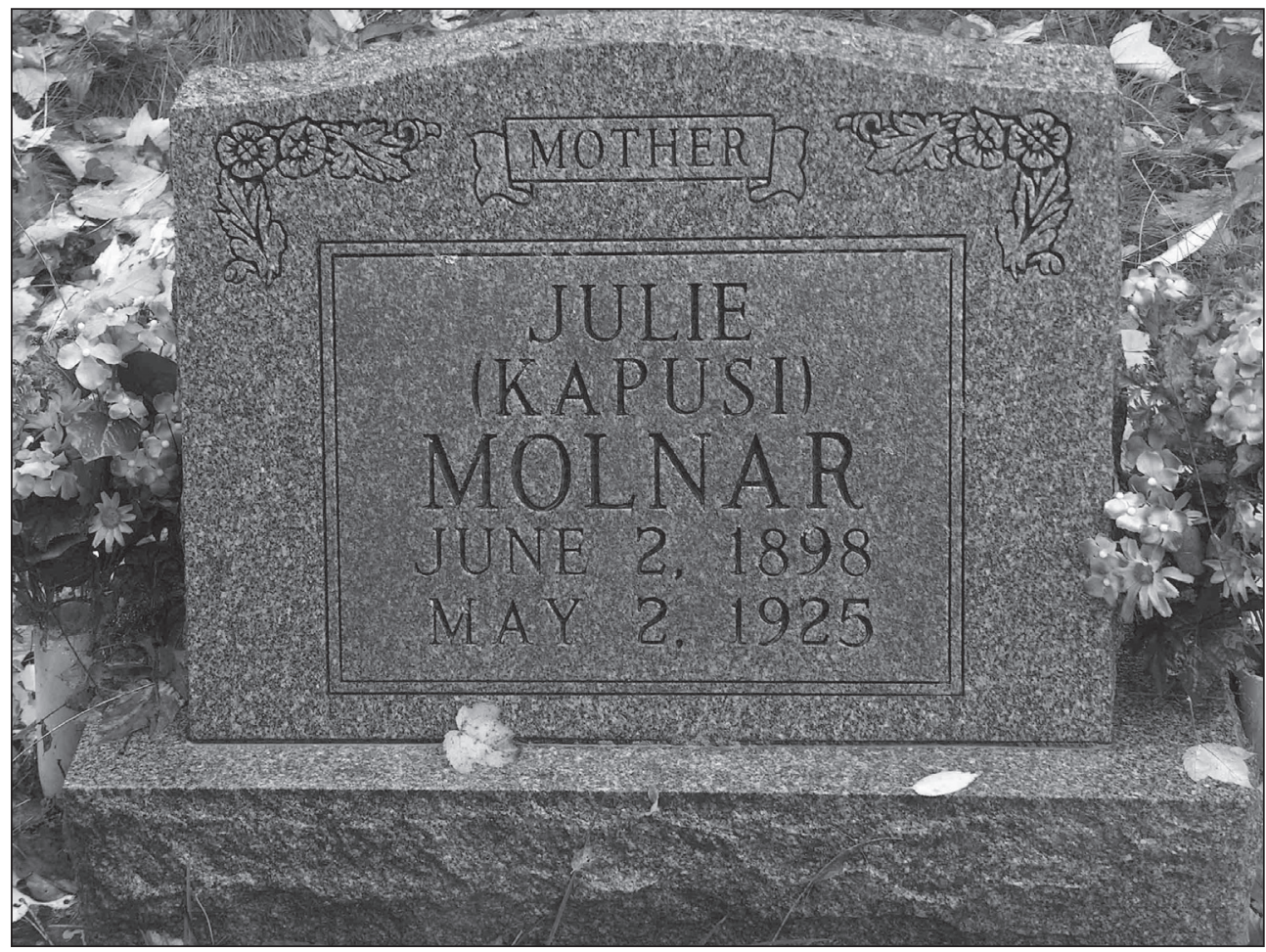

Figure 12. The gravesite of Júlia Kapusi in the Calvinist cemetery. Windber (PA) 2015. Photo by Balázs Balogh 


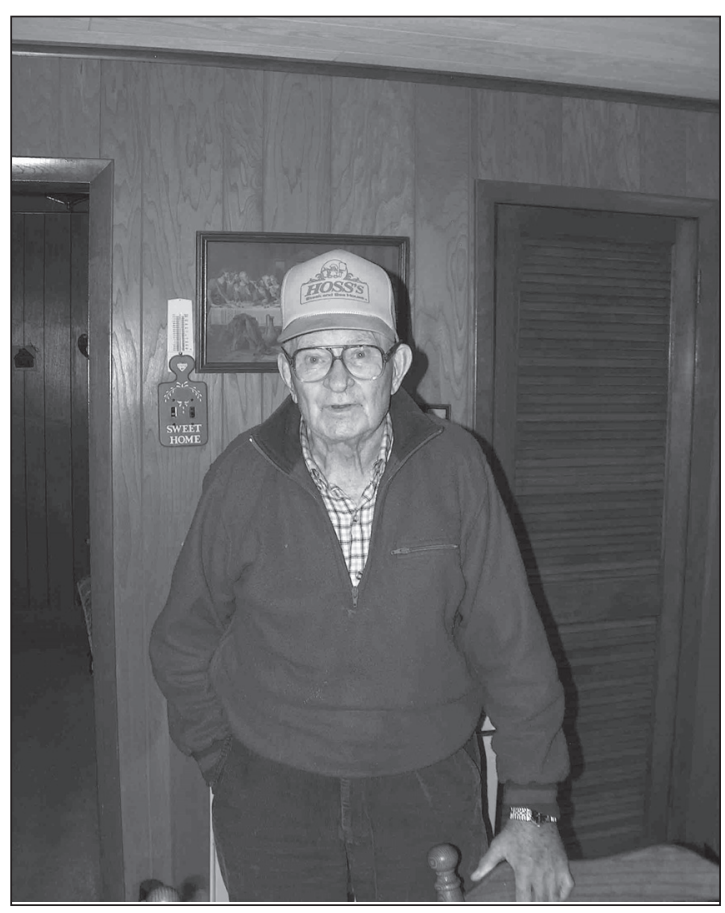

Figure 13. Alex Molnár in his home. Windber (PA) 2008. Photo by Balázs Balogh grocery store and meat market on the ground floor - could have survived intact with its original furnishings. (The museological significance of the building and its furnishings will be discussed later.) Such "archaisms" could not have survived in an organically developing, non-depopulated settlement.

In closing, I want to illustrate through a couple of examples the ways in which the information in documents can be enriched with additional data, material artifacts and related memories gathered in the course of fieldwork. What additional information can fieldwork provide? This issue is especially relevant in the research of Hungarian Americans, because it is a terrain that is very remote and hard to get to, but more and more documents ordered into databases are available on the Internet. For 100 USD per six months, one can have access through ancestry.com and other websites to the passenger manifests of emigrant ships, to the records of the Ellis Island Immigration Office, to US census records, scanned birth certificates, residential directories, etc. ${ }^{19}$ During fieldwork, however, the dry data of documents, such as death certificates, can only be interpreted in the context of individual life events. In these cases, the document becomes merely a supplementary data verifying the information gained in the field and the life story that emerges from the recollections, rather than remaining the one and only, dry source, free of all personal aspects.

The death certificate of J.K. accessible on ancestry.com (Figure 11) tells us that she was born in 1898 and committed suicide in 1925 . Her grave can be found in the Windber Reformed Cemetery. (Figure 12) In the field, I met M.A., her son, who was born in 1920. (Figure 13) I learned from him that his maternal grandfather ran a boarding house. When his daughter turned 15 years old, he gave her away to marry the miner that had offered the most money for her: "He sold my mother like an animal." Her husband, J.M., was a drunk who beat his wife. "My dad was a proud Mahdjar, oh yeah, with a big mustache." They had four children, and the informant was five years old when his mother committed suicide. The memoir, which is not being published here, paints a picture of the cruel men's

${ }^{19}$ Zoltán Fejös seeks to present the history of emigration of a settlement in Tiszahát merely based on documents accessible on the Internet (FEJÖs 2014). 
world of isolated mining colonies, where men literally had to fight each other to obtain women. It reveals life in the boarding houses, which was not conducive to romantic love affairs. Among the men confined together in small spaces, fighting, drinking, playing cards and murder were common (BALOGH 2017). M.A. recalled that his mother could no longer take the suffering, and her fate was not unique. Generally, little girls were married at the age of 14-15. "They were literally sold." When J.K. died, M.A., the only boy of the four children, stayed with his father, and his three sisters were taken by the grandparents. Throughout his childhood, M.A. feared his aggressive and belligerent father who did not even come home from the pub on the weekends. Many times, the neighbors invited him over and put him to bed.

Finally, let the following serve as an example of how the irreplaceable information gained in the field can help material artifacts tell their story. When I came across the Vintondale boarding house mentioned above with its entire original furnishings, it became clear that the Open Air Museum of Szentendre should buy it and bring it home to Hungary. And that is what we did - we surveyed the building with the Skanzen staff, documented all objects properly, packed them up, and brought them home. In the years before the survey, however, I interviewed the 98-year-old brother-in-law of the owner of the former convenience store and butcher shop. This elderly relative explained to me why the ceiling of the ground floor has a narrow opening to the upstairs bedroom covered with a wooden plank. The shop, which operated until 1929, could not sell spirits during the years of prohibition. But the shop owner stored his brandy and whiskey intended for sale in his room upstairs, lowering them with a rope to the salesperson "if the air was clean" and there was only one customer in the shop. Had there been no personal encounter in the field with the 98-year-old informant, we would have shipped the building without ever knowing why there was an opening in the ceiling of the store.

In both cases, we can see that there is knowledge one can only and exclusively acquire in the field, which can add irreplaceable additional information to the documents' data and to our knowledge of the material artifacts.

\section{REFERENCES CITED}

BALOGH, Balázs

2007 Vázlat a Nyugat-Pennsylvania-i magyar közösségek társadalmáról [Sketch of the Society of Hungarian Communities in Western Pennsylvania]. Ethnolore: A Magyar Tudományos Akadémia Néprajzi Kutatóintézetének Evkönyve XXIV:89-111.

2008 Cleveland magyar történetei [Cleveland's Hungarian Stories]. In SzENTKIRÁLYI, Endre (ed.) Clevelandben még élnek magyarok? Visszaemlékezések gyüjteménye, 8-13. Hungarian Scout Folk Ensemble.

2010a Lifestyle, Identity, and Visions of the Future of Hungarian-American Communities in Western Pennsylvania. Hungarian Heritage 11(1-2):19-33. Budapest: European Folklore Institute.

$2010 \mathrm{~b}$ Some Remarks about the Notion of Fatherland of American Hungarians. In: Bata, Tímea - Szarvas, Zsuzsa (eds.) Past and Present Stereotypes. Ethnological, Anthropological Perspectives. (Papers of the 10th Finnish- 
Hungarian Ethnological Symposium.), 151-160. Budapest: Hungarian Ethnographical Society (Magyar Néprajzi Társaság) - Museum of Ethnography (Néprajzi Múzeum).

2013 Ungarische Gemeinschaften in West-Pennsylvania [Hungarian Communities in West-Pennsylvania]. Jahrbuch für Europäische Ethnologie 8:231-248.

2015 A kivándorlók „,apoteózisa”. Festmény az amerikai magyar emigránsokról egy midwesti iparváros közkönyvtárában [The "Apotheosis" of Emigrants. A Painting of Hungarian Emigrants in America in the Public Library of a Midwestern Industrial Town]. Ethno-lore: A Magyar Tudományos Akadémia Bölcsészettudományi Kutatóközpont Néprajztudományi Intézetének Évkönyve XXXII:393-413.

2016 Az 1956-os magyar menekültek társadalmi integrációja az Egyesült Államokban [The Social Integration of 1956er Hungarian Refugees in the United States]. Világtörténet 2016(3):469-484.

2017 Az amerikai magyar „,burdosházak” a korabeli sajtó tükrében [Hungarian American Boarding Houses in Contemporary Media]. Ház és Ember 2829:337-348.

Brownstone, David M. - Franc, Irene M. - Brownstone, Douglass L.

1979 Island of Hope, Island of Tears. New York: Barnes \& Noble Books.

BRUBAKER, Roger

1996 Nationalism Reframed: Nationhood and the National Question in the New Europe. Cambridge: Cambridge University Press.

FEJös, Zoltán

1993 A chicagói magyarok két nemzedéke, 1890-1940. Az etnikai örökség megőrzése és változása. [Two Generations of Hungarians in Chicago, 18901940. The Preservation and Change of Ethnic Heritage]. Budapest: KözépEurópa Intézet.

2014 Cigándiak Amerikában [From Cigánd to America]. In VigA, Gyula (ed.) Fejezetek Cigánd néprajzából, 319-374. Cigánd: Önkormányzat.

JARVIS, William E.

2002 Time Capsules: A Cultural History. Jefferson, North Carolina and London: McFarland.

JENKS, Jeremiah W. - LAUCK, W. Jett

1913 The Immigration Problem: A Study of American Immigration Conditions and Needs. New York-London: Andesite Press.

JoNES, Maldwyn Allen

1992 American Immigration. Chicago: The University of Chicago Press. (The Chicago History of American Civilization).

NAGY, Károly

1984 Magyar szigetvilágban ma és holnap [Islands of Hungarians Today and Tomorrow]. New York: Püski.

PAPr Z., Attila

2008 Az amerikai magyar szervezeti élet és identitások értelmezési lehetőségei [Interpretations of Hungarian American Institutional Life and Identities]. In PApr Z., Attila (ed.) Beszédböl világ. Elemzések, adatok amerikai magyarokról, 397-425. Budapest: Magyar Külügyi Intézet. 
Puskás, Julianna

1981 The Process of Overseas Migration from East-Central Europe: Its Periods, Cycles and Characteristics. A Comparative Study. In MiodunkA, Wladyslaw BrozeK, Andrzej (eds.) Emigration from Northern, Central, and Southern Europe: Theoretical and Methodological Principles of Research, 33-51. Kraków (Zeszyty naukowe Uniwersytetu Jagiellońskiego, 732.).

1984 Kelet-Európából az USA-ba vándorlás folyamata, 1861-1924 [The Process of Migration from Eastern Europe to the USA, 1861-1924]. Történelmi Szemle 27(1-2):145-164.

SOUDERS, David Aaron

1922 The Magyars in America. New York: Doran.

SzÁNTÓ, Miklós

1984 Magyarok Amerikában [Hungarians in America]. Budapest: Gondolat. TÖRÖK, István

1978 Katolikus magyarok Észak-Amerikában [Catholic Hungarians in North America]. Youngstown.

VÁrDY, Bela Steven

1985 The Hungarian-Americans. Boston.

VÁrDY, Béla

2000 Magyarok az Újvilágban. Az észak-amerikai magyarság rendhagyó története [Hungarians in the New World. The Unusual History of North American Hungarians]. Budapest: A Magyar Nyelv és Kultúra Nemzetközi Társaság.

VÁRDY, Béla -VÁRdy HuszÁr, Ágnes

2005 Újvilági küzdelmek. Az amerikai magyarok élete és az óhaza [New World Struggles. Hungarian American Life and the Old Country]. Budapest: Mundus Magyar Egyetemi Kiadó.

Balázs Balogh is the Director of the Institute of Ethnology of Research Centre for the Humanities of Hungarian Academy of Sciences and Deputy Director General at the Research Centre for the Humanities of Hungarian Academy of Sciences, Budapest. He has PhD in European Ethnology and MA degrees in ethnography and Hungarian language and literature from ELTE, Budapest. Among others he was a visiting scholar at Indiana University, Bloomington with a HAESF grant for two years in 2006 and 2007, spent two months at the Social Anthropology Department of University of Cambridge in 1995, was a Herder grantees in Vienna for the year of 1992/93 at the Institute für Volkskunde an der Universitaet Wien and also spent a year at the Institut für Deutsche und Vergleichende Volkskunde an der Ludwig Maximillians Universitaet München in 1991/92 with a grant of Ministry of Culture of Bavaria. His fields of interest include various themes of social and economic anthropology; ethnic, interethnic minority issues; migration; changes of identity; Hungarian American and mining and industrial communities in the US and specifically in the Midwest; Ungarndeutschen communities in Hungary and Germany and rural Hungarian minority regions in Transylvania. He has written two books and more than hundred other publications. E-mail: balogh.balazs@btk.mta.hu 